\title{
Aplikasi Limbah Cair Pabrik Kelapa Sawit Dalam Memperbaiki Sifat Kimia Tanah Gambut
}

\author{
The Aplication Of Palm Oil Mill Effluent To Changes Of Chemical Properties Of Peat \\ Soil \\ ROSMALINDA $^{* 1}$, ANTO SUSANTO ${ }^{1}$ \\ ${ }^{1}$ Jurusan Pengelolaan Hasil Perkebunan, Politeknik Negeri Ketapang, Jl. Rangga Sentap- \\ Dalong, Kelurahan Sukaharja, Kecamatan Delta Pawan, Kabupaten Ketapang, \\ Kalimantan Barat 78813. Indonesia. \\ *Email : rosmalindasyaukani86@gmail.com
}

\begin{abstract}
The purpose of this study was to assess the effect of palm oil mill effluent (LCPKS) to changes of chemical properties of peat soil. The research was carried out by observation on oil palm plants that have produced. The results showed that there was an increase in pH value, macro nutrients and cation exchange capacity (CEC) on land applied to palm oil mill effluent compared to land without the application of palm oil mill effluent. Based on the results of chemical analysis of peat soil obtained values of $\mathrm{pH} 6.20, \mathrm{C}$-Organic 2.38\%, $\mathrm{N}$-Total $0.28 \%, \mathrm{P}_{2} \mathrm{O}_{5} 63.34 \mathrm{ppm}, \mathrm{Ca} 2.40 \mathrm{cmolkg}^{-1}, \mathrm{Mg} 1.37 \mathrm{cmolkg}^{-1}, \mathrm{~K} 1.06$

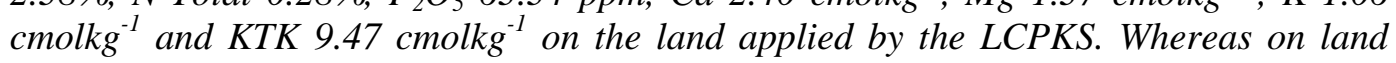
without LCPKS application pH values were obtained 3.24, C-Organic 46.80\%, N-Total $1.89 \%, \mathrm{P}_{2} \mathrm{O}_{5} 209.62 \mathrm{ppm}, \mathrm{Ca} 2.73 \mathrm{cmolkg}^{-1}, \mathrm{Mg} 0.73 \mathrm{cmolkg}^{-1}, \mathrm{~K} 0.36 \mathrm{cmolkg}^{-1}$ and CEC $87.23 \mathrm{cmolkg}^{-1}$.
\end{abstract}

Keywords : effluent, liquid, palm, peat, soil,

\begin{abstract}
ABSTRAK
Tujuan dari penelitian ini adalah mengetahui pengaruh aplikasi limbah cair pabrik kelapa sawit (LCPKS) terhadap perubahan sifat kimia tanah gambut. Penelitian dilakukan secara observasi pada tanaman kelapa sawit yang sudah menghasilkan. Hasil analisa kimia tanah menunjukkan bahwa bahwa ada peningkatan nilai $\mathrm{pH}$, unsur hara makro dan kapasitas tukar kation (KTK) pada lahan yang diaplikasi limbah cair kelapa sawit dibandingkan dengan lahan tanpa aplikasi limbah cair. Berdasarkan hasil analisa kimia tanah gambut diperoleh nilai $\mathrm{pH}$ 6,20, C-Organik 2,38\%, N-Total 0,28\%, $\mathrm{P}_{2} \mathrm{O}_{5} 63,34 \mathrm{ppm}$, Ca 2,40 $\mathrm{cmolkg}^{-1}, \mathrm{Mg} 1,37 \mathrm{cmolkg}^{-1}, \mathrm{~K} \quad 1,06 \mathrm{cmolkg}^{-1}$ dan KTK 9,47 $\mathrm{cmolkg}^{-1}$ pada lahan yang diaplikasi LCPKS. Sedangkan pada lahan tanpa aplikasi LCPKS diperoleh nilai pH 3,24, C-Organik 46,80\%, N-Total 1,89\%, $\mathrm{P}_{2} \mathrm{O}_{5} 209,62 \mathrm{ppm}, \mathrm{Ca} 2,73 \mathrm{cmolkg}^{-1}, \mathrm{Mg}$ 0,73 $\mathrm{cmolkg}^{-1}$, K $0,36 \mathrm{cmolkg}^{-1}$ dan KTK 87,23 $\mathrm{cmolkg}^{-1}$.
\end{abstract}

Kata kunci : limbah, cair, kelapa sawit, gambut, tanah 


\section{PENDAHULUAN}

Tanah gambut merupakan tanah yang terbentuk pada kondisi anaerob di lahan rawa. Tanah gambut mempunyai kandungan organik lebih dari 50 persen dan merupakan akumulasi sisa tanaman (Galbraith et al., 2005). Sehingga memungkinkan untuk dijadikan sebagai lahan budidaya. Namun pada tanah gambut biasanya terjadi defisiensi unsur mikro, terutama Tembaga $(\mathrm{Cu})$, Seng $(\mathrm{Zn})$, Ferrum $(\mathrm{Fe})$ dan Boron $(\mathrm{B})$ serta hara makro seperti Kalium (K), karena kandungan unsur-unsur tersebut di tanah gambut sangat rendah.Untuk mencapai produktivitas yang optimal di lahan gambut, maka perlu dilakukan pengelolaan.

Pengelolaan lahan gambut untuk usaha pertanian harus memperhatikan sifat fisika dan kimia tanah gambut. Kendala utama budidaya tanaman di lahan gambut adalah tingkat kemasaman tanah yang tinggi apabila dikaitkan dengan asam-asam organik beracun, rendahnya ketersediaan unsur hara makro dan mikro yang dibutuhkan tanaman yang diusahakan, permasalahan kebakaran lahan gambut, dan pengaturan tata air (Agus dkk., 2008).

Mengatasi masalah kandungan asam-asam organik yang beracun di lahan gambut biasanya dilakukan drainase dan penambahan bahan amelioran. Bahan amelioran (zat pembenah tanah) adalah bahan yang mampu memperbaiki atau membenahi kondisi fisik dan kesuburan tanah. Contoh bahan amelioran yang sering digunakan adalah kapur, tanah mineral, pupuk kandang, kompos, dan abu ( Subiksa, 2011).

Limbah cair pabrik kelapa sawit merupakan salah satu alternatif bahan amelioran yang dapat digunakan untuk memperbaiki sifat fisika dan kimia tanah gambut. 9 Limbah cair yang dihasilkan pabrik kelapa sawit mengandung bahan organik dan mineral cukup tinggi dengan Biological Oxygen Demand (BOD) sekitar $25000 \mathrm{mg} / \mathrm{L}$. Apabila dibuang langsung ke sungai atau perairan lainnya dapat menyebabkan penurunan kualitas lingkungan air dan tanah tempat pembuangannya. Selanjutnya akan menimbulkan pencemaran (Tobing dan Poeloengan, 2000). Apabila dilakukan pengelolaan dengan baik maka limbah cair kelapa sawit merupakan potensi yang cukup besar dan dapat meningkatkan nilai tambah limbah itu sendiri.

Limbah cair pabrik kelapa sawit mengandung unsur hara esensial yang berpotensi dimanfaatkan sebagai pupuk melalui land application dalam rangka meningkatkan kualitas lahan pertanian. Selain itu, limbah cair juga masih mengandung 
bahan organik (c-organik), sehingga dapat dijadikan sebagai bahan pembenah tanah (soil conditioner) (Banuwa, 2007).

\title{
METODE PENELITIAN
}

\begin{abstract}
Alat dan Bahan
Penelitian dilaksanakan di lokasi Perkebunan Kelapa Sawit Perusahaan PT. Kayung Agro Lestari (PT. KAL) Kecamatan Kuala Satong, Ketapang, Kalimantan Barat. Adapun alat yang digunakan terdiri dari meteran, ring tanah, dan wadah sampel. Bahan tanaman yang digunakan untuk penelitian adalah pohon kelapa sawit pada tanaman menghasilkan. Bahan-bahan lainnya adalah amplop coklat, kertas hvs, plastik dan karet.
\end{abstract}

\section{Prosedur Kerja}

Penelitian ini dilakukan secara observasi untuk melihat perubahan sifat kimia tanah gambut pada lahan yang diaplikasi limbah cair kelapa sawit dan lahan tanpa aplikasi limbah cair kelapa sawit pada tanaman kelapa sawit yang menghasilkan. Pertama-pertama ditentukan lahan yang akan diamati yaitu dengan tingkat kemiringan 0$3 \%$. Kemudian diambil sampel tanah menggunakan ring tanah masing-masing lahan sebanyak \pm 700 gram. Analisa kimia yang diamati meliputi nilai $\mathrm{pH}$, unsur N, P, K, Ca, $\mathrm{Mg}$ dan KTK. Analisa kimia tanah gambut dilakukan di Laboratotium Kimia dan Kesuburan Tanah UNTAN, Potianak.

\section{HASIL DAN PEMBAHASAN}

Permasalahan pertanian di lahan gambut adalah kemasaman gambut yang tinggi dan ketersediaan hara serta kejenuhan basa $(\mathrm{KB})$ yang rendah menyebabkan produksi pertanian di lahan gambut sangat rendah, sehingga untuk mengatasi permasalahan pada tanah gambut perlu dilakukan pemberian input yang besar untuk memperbaiki sifat-sifat tanah gambut (Najiyati dkk., 2005). Salah satu usaha yang dapat dilakukan untuk mengurangi penurunan dan mengembalikan kesuburan tanah gambut tersebut adalah dengan penggunaan limbah pabrik kelapa sawit.

Seiring dengan bertambah banyaknya perkebunan kelapa sawit di Kabupaten Ketapang, menjadikan limbah pabrik kelapa sawit semakin banyak. Dampak dari pertambahan pabrik kelapa sawit ini adalah bertambahnya bobot limbah yang harus 
dibuang, diantaranya adalah AB (abu boiler), LC (limbah cair) dan TK (tandan kosong). Selain digunakan sebagai pupuk, pemanfaatan limbah pabrik kelapa sawit ini juga mengurangi terjadinya pencemaran lingkungan.

Limbah cair pabrik kelapa sawit mempunyai beberapa manfaat seperti yang dinyatakan oleh Widhiastuti dkk., (2006) yaitu: dapat dijadikan pupuk karena pemberian limbah cair pabrik pengolahan kelapa sawit pada lahan perkebunan kelapa sawit dapat meningkatkan sifat fisik dan kimia tanah. Selain itu dapat meningkatkan biodiversitas tumbuhan penutup tanah dan menurunkan kehadiran gulma penting pada perkebunan kelapa sawit. Aplikasi limbah cair pada perkebunan kelapa sawit juga dapat meningkatkan biodiversitas makrofauna dan mesofauna tanah dan meningkatkan total bakteri tanah namun menurunkan bakteri Enterobacteriaceae yang merupakan kelompok bakteri penyebab penyakit. Hasil analisa kimia tanah gambut yang diaplikasikan limbah cair kelapa sawit dengan tanah gambut tanpa aplikasi limbah cair kelapa sawit dapat dilihat pada tabel berikut ini.

Tabel 1. Hasil Analisa Kimia Tanah Gambut Yang Diaplikasi Limbah Cair Kelapa Sawit dan Tanpa

\begin{tabular}{clll}
\multicolumn{3}{c}{ Aplikasi Limbah Cair Kelapa Sawit } \\
\hline No & Komponen & \multicolumn{1}{c}{ Aplikasi LCPKS } & \multicolumn{1}{c}{ Tanpa Aplikasi LCPKS } \\
\hline 1. & pH & 6.20 & 3.24 \\
2. & C-Org & $2.38 \%$ & $46.80 \%$ \\
3. & N-Total & $0.28 \%$ & $1.89 \%$ \\
4. & P2O5 & $63.34 \mathrm{ppm}$ & $209.62 \mathrm{ppm}$ \\
5. & $\mathrm{Ca}$ & $2.40 \mathrm{cmolkg}^{-1}$ & $2.73 \mathrm{cmolkg}^{-1}$ \\
6. & $\mathrm{Mg}$ & $1.37 \mathrm{cmolkg}^{-1}$ & $0.73 \mathrm{cmolkg}^{-1}$ \\
7. & K & $1.06 \mathrm{cmolkg}^{-1}$ & $0.36 \mathrm{cmolkg}^{-1}$ \\
8. & KTK & $9.47 \mathrm{cmolkg}^{-1}$ & $87.23 \mathrm{cmolkg}^{-1}$ \\
\hline
\end{tabular}

\section{pH Tanah}

$\mathrm{pH}$ tanah merupakan unsur yang sangat penting karena mengandung nitrogen $(\mathrm{N})$, potassium $(\mathrm{K})$, dan Phosphorus $(\mathrm{P})$ yang dibutuhkan tumbuhan untuk berkembang. Jika pH tanah dibawah 5,5 maka tumbuhan dapat membentuk nitrogen dalam bentuk nitrat. Sedangkan Phosphorus ada pada pH tanah antara 6 dan 7. Tingkat keasaman tanah disebabakan oleh leaching mineral, dekomposisi tumbuhan (seperti pohon jarum), limbah industri, hujan asam, dan beberapa bentuk aktivitas mikrobiologi (Harjdjowigeno, 2007).

Berdasarkan hasil analisis tanah, nilai $\mathrm{pH}$ tanah gambut yang diaplikasi limbah cair kelapa sawit mengalami peningkatan dibandingkan lahan tanpa aplikasi limbah cair kelapa sawit, yaitu dari 3,24 menjadi 6,20. Menurut Sulistiyanto (2015) pemberian limbah cair kelapa sawit menunjukkan peningkatan nilai $\mathrm{pH}$ terbaik dibandingkan limbah 
pabrik yang lain seperti abu boiler dan tandan kosong. Hal ini dikarenakan jenis limbah yang berbentuk cair menjadikan limbah ini mudah tercampur dan unsur-unsur yang terkandung lebih cepat berikatan.

Pada umumnya, hara mudah diserap akar pada $\mathrm{pH}$ sekitar netral karena pada $\mathrm{pH}$ tersebut, hara mudah larut dalam air. Pada tanah masam ditemukan unsur-unsur beracun. Hal ini disebabkan oleh terjadinya peningkatan kelarutan unsur mikro ( $\mathrm{Fe}, \mathrm{Mn}, \mathrm{Zn}, \mathrm{Cu}$ dan Co) pada jumlah yang besar sehingga bersifat toksik bagi tanaman, sedangkan Mo akan bersifat racun pada $\mathrm{pH}$ yang terlalu alkalin. Selain itu $\mathrm{pH}$ tanah juga menentukan perkembangan dan populasi mikroba tanah. Bakteri dan jamur yang bermanfaat bagi tanah dan tanaman akan berkembang biak pada $\mathrm{pH}>5,5$ apabila $\mathrm{pH}$ tanah terlalu rendah maka akan terhambat aktivitasnya (Munawar, 2011).

\section{Ketersediaan Hara Makro}

Ketersediaan $\mathrm{N}$ bagi tanaman pada tanah gambut umumnya rendah, walaupun analisis N-total umumnya relatif tinggi karena berasal dari N-organik. Perbandingan kandungan $\mathrm{C}$ dan $\mathrm{N}$ tanah gambut relatif tinggi, umumnya berkisar 20-45 dan meningkat dengan semakin meningkatnya kedalaman tanah (Radjagukguk, 1997). Oleh karena itu untuk mencukupi kebutuhan $\mathrm{N}$ tanaman yang optimum diperlukan pemupukan $\mathrm{N}$. Berdasarkan hasil analisa, nilai N-total pada lahan yang diaplikasi limbah cair lebih rendah yaitu $0,28 \%$ dibandingkan dengan lahan tanpa aplikasi yaitu 1,89\%. Hal ini berbeda dengan penelitian yang dilakukan Widhiastuti dkk., (2006), yang menyatakan bahwa pemberian limbah cair kelapa sawit ke lahan perkebunan kelapa sawit selama 12 tahun dapat meningkatkan jumlah $\mathrm{N}$-total pada lahan tersebut. Hal ini diduga karena pada lahan tanpa aplikasi limbah cair, tetap diberikan pupuk sehingga hasilnya tidak memberikan perbedaan.

Unsur fosfor $(\mathrm{P})$ pada tanah gambut sebagian besar dijumpai dalam bentuk Porganik, yang selanjutnya akan mengalami proses mineralisasi menjadi P-anorganik oleh jasad mikro. Sebagian besar senyawa P-organik berada dalam bentuk ester ortofosfat, sebagian lagi dalam bentuk mono dan diester. Ester yang telah diidentifikasi terdiri atas inositol fosfat, fosfolipid, asam nukleat, nukleotida, dan gula fosfat. Ketiga senyawa pertama bersifat dominan.

Berdasarkan hasil analisa tanah, nilai P pada lahan yang diaplikasi limbah cair adalah 63,34 ppm, sedangkan pada lahan tanpa aplikasi nilai P adalah 209,62 ppm. Fraksi P-organik diperkirakan mengandung 2,0\% $\mathrm{P}$ sebagai asam nukleat, 1,0\% sebagai 
fosfolipid, 35\% inositol fosfat, dan sisanya belum teridentifikasi. Di dalam tanah, pelepasan inositol fosfat sangat lambat dibandingkan ester lainnya, sehingga senyawa ini banyak terakumulasi, dan kadarnya didalam tanah menempati lebih dari setengah Porganik atau kira-kira seperempat total $\mathrm{P}$ tanah. Senyawa inositol heksafosfat dapat bereaksi dengan $\mathrm{Fe}$ atau $\mathrm{Al}$ membentuk garam yang sukar larut, demikian juga terhadap Ca. Dalam keadaan demikian, garam ini sukar didegradasi oleh mikroorganisme (Stevenson, 1984).

Keberadaan unsur hara $\mathrm{P}$ sangat erat kaitannya dengan $\mathrm{pH}$ tanah, semakin tinggi tingkat kemasaman tanah maka unsur $\mathrm{P}$ menjadi semakin tidak tersedia. Posfor adalah unsur hara yang mudah terikat dengan unsur lain. Sebagian besar P terikat oleh partikel tanah dan sebagian organik dan hanya sedikit sekali dalam bentuk tersedia dalam larutan tanah (Adiningsih, 1987).

Berdasarkan hasil analisa kandungan Ca pada lahan yang diaplikasi limbah cair adalah 2,40 cmolkg-1 sedangkan pada lahan tanpa aplikasi nilai Ca adalah 2,73 $\mathrm{cmolkg}^{-1}$. Keberadaan $\mathrm{Ca}$ dalam tanah sangat dipengaruhi oleh $\mathrm{pH}$ tanah. Menurut Chang dan Khun (1986) kebeberadaan unsur P dan Ca dalam tanah di pengaruhi oleh $\mathrm{pH}$ tanah, pada tanah yang memiliki $\mathrm{pH}$ rendah akan miskin unsur $\mathrm{P}$ dan $\mathrm{Ca}$. Rendahnya $\mathrm{Ca}$ dipengaruhi oleh nilai $\mathrm{pH}$ tanah yang rendah, bahan organik rendah dan tekstur tanah pasir (Supriyadi, 2007).

Pemberian limbah cair kelapa sawit pada lahan mampu meningkatkan nilai $\mathrm{Mg}$ $\left(1,37 \mathrm{cmolkg}^{-1}\right)$ dibandingkan dengan lahan tanpa aplikasi limbah cair $\left(0,73 \mathrm{cmolkg}^{-1}\right)$. Hal ini didukung oleh penelitian Prayitno dkk., (2007) yang menyatakan perlakuan limbah cair yang diaplikasikan lebih baik dibanding tandan kosong karena limbah cair memiliki bentuk cair ketika diaplikasikan sehingga akan dapat mudah langsung diserap oleh tanaman.

\section{Kapasitas Tukar Kation (KTK)}

Kapasitas tukar kation (KTK) pada tanah gambut sangat tinggi, berkisar 100-300 me $100 \mathrm{~g}^{-1}$ berdasarkan berat kering mutlak (Hartatik dan Suriadikarta, 2006). Tingginya nilai KTK tersebut disebabkan oleh muatan negatif tergantung $\mathrm{pH}$ yang sebagian besar berasal dari gugus karboksilat dan fenolat, dengan kontribusi terhadap KTK sebesar 10 $30 \%$ dan penyumbang terbesarnya adalah derivat fraksi lignin yang tergantung muatan 64 -74\% (Charman, 2002). Berdasarkan hasil analisa kimia, nilai KTK pada lahan yang diaplikasi limbah cair lebih rendah yaitu $9,47 \mathrm{cmolkg}^{-1}$ dibandingkan lahan tanpa aplikasi 
limbah cair dengan nilai $87,23 \mathrm{cmolkg}^{-1}$. Menurut Maas (1997) tingginya nilai KTK menyebabkan tanggapan tanah terhadap reaksi asam-basa dalam larutan tanah untuk mencapai kesetimbangan memerlukan lebih banyak reaktan (amelioran).

\section{KESIMPULAN}

Berdasarkan hasil penelitian dapat disimpulkan bahwa terjadi perubahan komposisi untuk nilai $\mathrm{pH}$ dan kandungan mineral pada tanah gambut setelah diaplikasi limbah cair pabrik kelapa sawit. Dengan nilai pH 6,20, C-Organik 2,38\%, N-Total 0,28\%

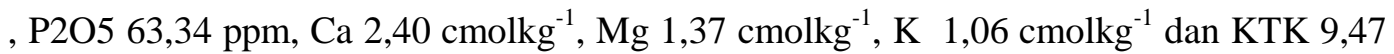
cmolkg-1.

\section{UCAPAN TERIMA KASIH}

Terima kasih yang sebesar-besarnya disampaikan kepada semua pihak, khususnya kepada lembaga penyandang dana, Ditjen Dikti, yang telah mempercayakan kepada kami, dengan dana daftar isian pelaksana anggaran (DIPA 2018).

\section{DAFTAR PUSTAKA}

Agus, F. dan I.G.M. Subiksa. 2008. Lahan Gambut : Potensi untuk Pertanian dan Aspek Lingkungan. Bogor: Balai Penelitian Tanah. 36p.

Banuwa, I. S. 2007. Studi kandungan hara dan bahan pencemar limbah cair pabrik kelapa sawit untuk meningkatkan kualitas lahan pertanian. Jurnal Agroland 14(2):106110.

Charman, D. 2002. Peatlands and Environmental Change. John Wiley \& Sons. Ltd. England.

Galbraith, H., Amerasinghe, P \& Lee, H.A. 2005. The effects of Agricultural Irrigation on Wetland Ecosystems in Developing Countries: A literature review. CA Discussion Paper 1 Colombo, Sri Lanka: Comprehensive Assessment Secretariat.

Hartatik, W. dan D.A. Suriadikarta. 2006. Teknologi pengelolaan hara lahan gambut. Dalam I. Las (Ed.). Karakteristik dan Pengelolaan Lahan Rawa. Balai Besar Penelitian dan Pengembangan Sumberdaya Lahan Pertanian. Bogor.

Maas, A. 1997. Pengelolaan lahan gambut yang berkelanjutan dan berwawasan lingkungan. Jurnal Alami 2(1):12-16. 
Najiyati, S., L. Muslihat dan INN.Suryadiputra. 2005. Panduan Pengelolaan Lahan Gambut Untuk Pertanian Berkelanjutan. Wetland International - Indonesia Programme.

Prayitno, S., D. Indradewa dan B.H. Soenarminto. 2007. Produktivitas Kelapa Sawit (Elaeis guineensis Jacq.) yang Dipupuk dengan Tandan Kosong dan Limbah Cair Pabrik Kelapa Sawit. Jurnal PTPN. Lampung Selatan,Volume 15, No .1 .

Radjagukguk, B. 1997. Peat soil of Indonesia: Location, classification, and problems for sustainability. In: Rieley and Page (Eds.). pp. 45-54. Biodiversity and sustainability of tropical peat and peatland. Samara Publishing Ltd. Cardigan. UK.

Subiksa, I.G.M., W.Hartatik dan F. Agus. 2011. Pengelolaan Lahan Gambut Secara Berkelanjutan.http://balittanah.litbang.deptan.go.id.

Sulistiyanto, Y. Amelia, V. Kamillah dan Rassid. 2015. Perubahan Sifat Kimia Tanah Gambut Setelah Pemberian Limbah Pabrik Kelapa Sawit. Jurnal AGRI PEAT, Volume 16, No.2 : 114-121.

Supriyadi, S. 2007. Kesuburan Tanah di Lahan Kering. Madura. Embryo, Jurnal Ilmuilmu Pertanian. Vol.4:2; 124-131.

Tobing, P.L. dan Z. Poeloengan. 2000. Pengendalian Limbah Cair Pabrik Kelapa Sawit secara Biologis di Indonesia. Warta PPKS 8(2):99-106.

Widhiastuti, R., D. Suryanto, Mukhlis, H. Wahyuningsih. 2006. Pengaruh pemanfaatan limbah cair pabrik kelapa sawit sebagai pupuk terhadap biodiversitas tanah. Jurnal Ilmiah Pertanian Kultura 41(1). 